\title{
Hvorledes kom Grundtvig til at oversætte Saxo og Snorre?
}

\author{
Af Steen Fohansen.
}

Det er i år 150 år siden, at Grundtvig udsendte første bind af sin oversættelse af Saxos Danmarkshistorie og af Snorre Sturlesøns norske kongesagaer. Udgivelsen ( 1818) var - med eller mod Grundtvigs vilje - omgivet af kolossal offentlig interesse, en sensation, som vist næppe tidligere var blevet noget dansk bogværk til del. Sensationen holdt dog ikke længe. Udsendelsen af de næste dele af værket ( I8I9) forløb stilfærdigt, og de sidste dele udkom i sommeren 1823 uden ringeste opmærksomhed fra publikums side, - til uhyre skuffelse for Grundtvig.

Om alle bøger gælder det vel i almindelighed, at deres eksistens naturligvis er vigtigere end deres tilblivelseshistorie (eller editionshistorie). Og dog er der ikke få tilfælde, hvor f. eks. et manuskripts fundhistorie og påfølgende udgivelse i sig selv kan være et værdifuldt led i et lands kulturelle eller litterære udvikling. Også spørgsmål om udgivelsesmåden (f. eks. pr. subskription) eller censurforhold kan eller kunde have interesse i sig selv, og for oversættelsers vedkommende har valget af oversætter ikke sjældent haft en vis litterær betydning. I det følgende skal vi dog ikke gå nøjere ind hverken på kvaliteten af Grundtvigs to krønikeoversættelser eller på deres editionshistorie som sådan. En beskrivelse af denne sidste vilde fylde en hel bog for sig, da kildematerialet er meget omfattende. Men vi vil her blot slå ned på begyndelsen til det hele. Hvorledes gik det til, da Grundtvig blev valgt til oversætter?

I.

Et blik på originaludgavernes titelblade viser os straks, at værkerne ikke udsendtes af et forlag, men var »bekostet af Krønikens Danske 
og Norske Venner $\left.\ll^{1}\right)$. Vil man vide mere, kan man i hvert værks fortale læse Grundtvigs kortfattede fremstilling af, hvorledes han kom til at oversætte krønikerne. Disse to fremstillinger er dog ikke lidt forskellige indbyrdes og unægtelig meget subjektive, tillige noget upræcise i realia. På basis af bevarede skrivelser og breve m. m. tager det hele sig noget anderledes ud, og om valget af ham til oversætter udtaler han sig næsten ikke.

Den historiske baggrund for krønikernes udgivelse var Napoleontidens urolige forhold og de deraf følgende nationale vækkelser rundt om i landene. På grund af krigen med England blev Danmark og Norge isoleret fra hinanden, hvad der i dobbeltmonarkiet DanmarkNorge førte til en voksende interesse for Norge, først og fremmest naturligvis i Norge selv, men også i Danmark. Det stærkeste udslag heraf var stiftelsen af »Selskabet for Norges Vel « i Oslo i slutningen af i 8og. Dette selskab fik hurtig en stor, også politisk og økonomisk, indflydelse. Dets nærmeste opgave var forøvrigt at få oprettet et norsk universitet, en opgave, der også omgående blev løst.

»Selskabet for Norges Vel « mødte stor sympati i Danmark, hvad der i april-maj I8I I førte til oprettelsen af en dansk afdeling i København. Denne kom til at bestå af 229 medlemmer, hvoriblandt f. eks. Grundtvig, Baggesen, Treschow samt Gr.s norske venner Hersleb, Stenersen, Sverdrup og Wexels. (Sidstnævnte blev dog først langt senere ven med Gr.) $)^{2}$ ). Selskabets ledere i Kbh. var højesteretsadvokat W.F.Treschow og den norskfødte døvstummepædagog P.A. Castberg; også professor Sverdrup indtog en ledende stilling i selskabet. - I Norge var selskabet delt i syv klasser eller hovedkommissioner, hvoraf $\mathrm{nr}$. tre udgjorde $\gg$ den historisk-filosofiske klasse«, som lededes af overlærer, senere professor L. Stoud Platou, slotspræst C. Pavels og pastor Niels Wulfsberg. Stoud Platou var dengang overlærer ved Oslo katedralskole, og en anden overlærer ved samme skole var den klassiske filolog og leksikograf Paul Arnesen (I 776-I87I). Arnesen var islænder af fødsel, student fra Helsingør, I 803 adjunkt i Oslo, I 806 overlærer samme sted.

I. Hver krønike udkom i 3000 eksemplarer. Heraf bar I ooo eks. den anførte angivelse forneden på titelbladet; disse eks. solgtes i den frie handel i København. I de øvrige 2000 eks. lød linien: Bekostet for Menig-Mand af Krønikens (osv.). Disse eks. fordeltes rundt om i landet til dem (eller de institutioner, skoler m. v.), som havde bestilt værkerne forud ved at yde pengebidrag (og som derfor fik dem til en meget billig pris).

2. Medlemslisten, se Gr.-arkivet fascikel $247, \mathrm{I}, \mathrm{I}$. 
Under 6. november I81 o indgav Arnesen til selskabet en skriftlig henvendelse, hvori han udtalte, at det burde sørge for en ny og tidssvarende udgave af Snorres kongesagaer. Han tilbød samtidig at oversætte sagaerne, dog fraregnet versene, som han mente burde udelades, fordi de var vanskelige at oversætte og forstå, og som, hvis de medtoges, også vilde fordyre bogens pris. Kommissionen for tredie klasse anbefalede Arnesens idé m. h.t. udgivelsen, men som oversætter foreslog den pastor, dr. Einar Gudmundsson i Sørum (Akers fylke). Denne mand, som var islænder af fødsel, var især kendt for sin oversættelse til islandsk af N. E. Balles overalt brugte lærebog i den evangelisk-kristelige religion. Det var meningen, at Gudmundssons oversættelse dernæst skulde gennemses og revideres af filologen, professor fón Ólafsson, en af datidens lærde kendere af den islandske sagatids sprog og litteratur. (Han havde i sin tid moderniseret Peder Claussøns gamle Snorre-oversættelse i den videnskabelige udgave af grundteksten I 777 ff.) Også Paul Arnesen skulde gennemse oversættelsen inden trykningen. Hvad kvadene angik, så mente kommissionen, at de ikke burde udelades, men at man f. eks. burde henvende sig til Oehlenschläger og bede ham oversætte dem. Oplagets størrelse fastsattes til 2000 eksemplarer i to kvartbind.

Så vidt de oprindelige planer. Men pastor Gudmundsson sagde nej til oversættelsesarbejdet, og det samme sagde Jón Ólafsson, der $\mathrm{i}$ stedet for henviste selskabet til Arnesen selv som den bedst egnede. Arnesen gav da sit tilsagn m.h.t. at oversætte prosaen, medens spørgsmålet om oversættelsen af versene foreløbig henstod uafklaret. Muligvis har det været nævnelsen af Oehlenschläger, der bevirkede, at sagen ved årets slutning blev oversendt til København. I Københavnsafdelingen blev på et møde den 3. jan. I8 12 oplæst en skrivelse fra direktionen i Oslo samt Arnesens erklæring om en ny oversættelse af Snorre, og prof. Sverdrup gav nøjere forklaring. Der blev derefter nedsat en komité, som fik til opgave at udarbejde en betænkning.

Komiteen, som bestod af 6 medlemmer, hvoriblandt Treschow og Hersleb, afgav 1 2. februar en betænkning (fire kvartsider) ${ }^{3}$ ). Hvad der mest interesserer os $\mathrm{i}$ denne er, at det af teksten indirekte fremgik, at man, dvs. Hersleb, engang i i 8 I I (eller i hvert fald før betænkningens dato) uofficielt havde henvendt sig til pastor Grundtvig og bedt ham »revidere« Arnesens kommende oversættelse af

3. Fasc. $247,1,2$. 
Snorre, samt at Gr., ligeledes uofficielt, havde indvilliget heri. I betænkningen siges det nu videre (henimod slutningen), at hvis hr. Arnesen selv skulde ønske kyndige mænds råd og vejledning til sit oversætterarbejde, kunde man måske officielt opfordre Grundtvig til at oversætte det metriske hos Snorre og tillige bede ham række Arnesen en »venskabelig Haand til det vigtige Værks muligt fuldkomne Udførelse «. Bag denne udtalelse lå utvivlsomt Herslebs indflydelse, han var jo nær ven af Gr. fra kollegieårene på Valkendorf. Oehlenschläger omtales ikke og synes helt at være gledet ud som oversætteremne, og nogen henvendelse til ham kendes ikke. Iøvrigt indeholdt betænkningen interessante betragtninger over den kommende oversættelses karakter: hvor moderne og nutidig skal den være i forhold til Peder Claussøns gamle oversættelse? Da den bør være beregnet på almuens fordringer, må den ikke være alt for nymodens, eftersom almuen jo gerne hænger ved det gamle. Dette drøftes frem og tilbage, uden endelig stillingtagen. Men også her dukker Grundtvigs navn op. Man kunde - hedder det - tænke sig en oversættelse i vor tidsalders sprog eller i fortidens ånd og sprog, »saaledes som i Vaulundurs Saga findes et andet Sprog end i Hakon Jarl, og saaledes som Gräters Oversættelse af Fortællingen om Sværdet Tyrfing vist nok har en ganske anden Tone end Grundtvigs«. Her tænkes bl. a. på nytårsgaven »Idunna« ( I8 I I ), hvor Gr. i nænsom saga-efterlignende stil havde oversat det afsnit af Hervors saga, som handler om sværdet Tyrfing eller Tirfing.

Denne betænkning sendtes nu til hovedkvarteret i Oslo, hvor selskabets direktion på et møde den 25. maj 181 2 vedtog helt at akceptere Arnesen som oversætter, hvem det dernæst blev pålagt at være færdig med arbejdet i sommeren 1814. Arnesen skulde endvidere underrettes om, at selskabet havde anmodet Gr. om at oversætte versene hos Snorre, jf. herom nedenfor. Disse bestemmelser ${ }^{4}$ ) blev pr. 6. juni oversendt til København, og samme dag sendte selskabet i Oslo en skrivelse direkte til Grundtvig i Udby ${ }^{5}$ ). Dermed var den første officielle og direkte kontakt mellem Gr. og »Selskabet for Norges Vel« oprettet.

Af denne skrivelse fremgik for det første, at Gr. i forårshalvåret I8 2 gennem Sverdrup faktisk havde tilbudt selskabet at oversætte kvadene i Snorre, hvis man vel at mærke overlod valget af den,

4. Fasc. $247,1,3$.

5. Fasc. $247,1,4$. 
der skulde oversætte prosaen, til ham! Endvidere havde Gr. ved samme lejlighed tilbudt at skrive en fortsættelse af Snorres historie. Hertil havde selskabet nu først at bemærke, at det med glæde modtog Gr.s tilbud om at oversætte kvadene, og man ønskede så få som muligt af dem udeladt. Angående hovedpunktet, valget af en oversætter af prosaen, udtalte direktionen følgende: $\gg \mathrm{Da}$ vi formode, at Hr. Overlærer Arnesen vedbliver Oversættelsen af Snorros prosaiske Indhold, i Følge sit for omtrent ${ }_{1}^{1 / 2}$ Aar tilbage indgivne Forslag og senere Bestemmelser desangaaende, saa have vi tillige tilskrevet den Kjøbenhavnske Commission, at anmode Overlærer Arnesen om, at conferere med Deres Velærværdighed angaaende denne nye Udgave af Snorro, ligesom vi ogsaa herved bruge Frihed tjenstligst at anmode Hr. Pastoren om, at De med lige Velvillie vil understøtte baade med Raad og Daad Overlærer Arnesen ved Oversættelsen af dette Norske national Verk «.

Selskabet fastholdt således Arnesen som oversætter og undgik helt at udtale sig om Grundtvigs føranførte betingelse. Hvorledes Arnesen har reageret på forslaget om et eventuelt samarbejde med Gr., vides ikke.

Den 24. juli I 8 I 2 besvarede Grundtvig denne skrivelse med et længere brev, hvori han bl. a. skrev følgende om versene i Snorre og deres oversættelse (her citeret og refereret efter den bevarede koncept) : »Stort poetisk Værd have, som bekendt, de fleste Vers i Snorro ikke, saasom de alle ere fra det Tidsrum under og efter Harald Haarfager da kunstig Versebygning og pralende Ord skulde erstatte Mangelen paa høie Tanker og ukunstlet Ynde, men gør det, naturligviis, som de fleste af vor Tids Surrogater, kun for Børn og Narre. Imidlertid er der stor Forskiel, Eivind Skaldespiller havde herlige lyse Øieblikke, hos Thjodolf findes mangengang en gribende, trohjertig Vending midt i den brammende Ordkløgt. Nu tænker jeg som saa, hvor Saadant findes der hjemler det Verset Ret til Oversættelse, men hvor Kunsten mere bestaar i høitravende mest mythologiske Ord, eller hvor det slet ikke indeholder Andet end hvad der staar foran i Prosa, synes det mig ei Umagen værd at spilde Tid og Ord, aldenstund Lægmand ei deri kan finde mindste Behag eller Forstand. At Versene for en Gransker baade som Stadfæstelse og Vidnesbyrd altid blive mærkværdige er en anden Sag. Dette om Valget og hvad nu Oversættelsen angaaer da gør jeg mig til Lov at give Meningen, saavidt jeg kan komme efter den uforfalsket«. Gr. vil 
dog ikke være ordenes slave, en helt bogstavelig oversættelse vilde let blive uforståelig for menigmand. Mytologiske ord og navne bør undgås; skulde de med, måtte der forklaringer til, der vel kunde give de få den fornødne kundskab, men var unyttig for mange. »Een Vanskelighed vil jeg imidlertid ikke fortie, nemlig at det deiligste Vers i hele Snorro: Eivinds Ligsang over Hakon Adelsten er aldeles uforstaaelig uden Kommentar, fordi det ei blot som de andre har mythologiske Ord men en mythisk Bygning. Den eneste Udvei her var ved en lemplig Forvandling at gøre Digtet kristeligt. Rigtig nok var det da ei længer det samme, men sømmeligere blev det over en kristen Konge, og i Grunden klinger det dog heel naragtigt, naar Valhals Afguder rose en kristen Konge, fordi han saa vel har æret Helligdommene $\left.\ll^{6}\right)$.

Af dette citat (og iøvrigt af andre udtalelser $i$ datiden) forstår man i hvilken grad det dengang, da sagastudiet var i sin vorden, har været et problem at oversætte de islandske skjaldevers, som virkelig også stadig er et af de vanskeligste oversættelsesproblemer overhovedet. (I den gamle oversættelse havde man, så godt eller dårligt man formåede, gengivet dem i prosa). Grundtvig vil skelne mellem middelmådige vers og gode og helst kun oversætte de sidste. Men hvad man mest lægger mærke til, er hans forslag om at »kristne« Hákonarmál. Det er den »bibelske« Gr., som her dukker op. Efter krisen 1810-1 I var han mere ivrig end nogen sinde efter at se og fortolke alt: historien, oplysningstiden, den nordiske oldtid samt forholdet Danmark-Norge i lys af bibelens tale. Han arbejdede netop ved denne tid på sin første »Verdenskrønike«, hvori han i en rivende veltalende form gav luft for sit nye syn. Også et kvad hos Snorre burde ændres i kristelig retning, hvis han skulde oversætte $\operatorname{det}$ !

Senere i samme brev trak han sit tidligere tilbud om at fortsætte Snorre tilbage, men undlod dog ikke $\mathrm{i}$ brevet at brede sig udførligt om, hvorledes han havde tænkt sig, at denne fortsættelse skulde forme $\operatorname{sig}^{7}$ ).

Grundtvigs brev blev oplæst på et møde i København den 7 . august. Hersleb var til stede, og Gr.s tanker om at ændre Eyvinds kvad på føromtalte måde, fik ham til øjeblikkelig at skrive til Gr.

6. Fasc. 247,1,6. - Slutningsordene »fordi han saa vel har æret Helligdommene« lyder i Svend Gr.s afskrift (i fasc. 478): »fordi han saa ofte har æret Helligdommen«, hvilket vistnok er en fejllæsning.

7. Denne del af brevet er gengivet i Birkelands bog s. $63-65$. 
(I I. aug): »Hvad mig angaar, saa havde jeg rigtig nok stor Lyst til, naar jeg turde, at spørge Dem om, hvorledes og hvorfor Ejvinds Sang skulde kristnes? ... Tror De, at denne Sang kan forarge eller vel endog forføre Almuen til Afguderi? Det kan jeg dog umulig forestille mig $\left.\ll^{8}\right)$.

Den 4. sept. I8I 2 takkede Københavnsledelsen Grundtvig, fordi han havde erklæret sig villig til at oversætte versene hos Snorre. Man bifaldt hans principper, men frarådede ham at ændre noget i Eyvinds sang »af den Grund, Deres Velærværdighed selv har anført, at Digtet da ei længere blev heelt sig selv. Da Deres Velærværdighed har havt den Godhed at overlade dette til vort Skjøn, ville vi derfor ei tilbagekalde det Ønske at det maatte gives som det $\left.\mathrm{er}{ }^{9}\right)$.

$\mathrm{Nu}$ fulgte et tidsafsnit, efteråret og vinteren I $_{8}$ I $_{2}-\mathrm{I}_{3}$, hvor der ikke skete noget nyt i sagen. Hvorledes gik det med Arnesens oversættelse? Det gik slet ikke. I i 8 I 2 tog han afsked fra skolen i Oslo og bosatte sig I8I3 i Slagelse som lærer ved latinskolen. Han følte sig fornærmet over, at han ikke fik noget svar på de »notitser«, han i jan I8I 2 havde sendt selskabet angående oversættelsen. Dertil kom forandringen i hans litterære og borgerlige forhold (overflytningen til Danmark), som sammen med andre sysler helt synes at have afbrudt oversættelsesarbejdet (hvis det overhovedet var kommet i gang). Alt dette meddelte han i al korthed selskabet i et brev af 4. marts I8I 3 og oplyste tillige, at han foreløbig ikke kunde levere den forlangte prøve på arbejdet. I et nyt brev i maj meddelte han, at han helt opgav oversættelsen og gerne ønskede arbejdet overdraget til en anden. Dermed gled Arnesen ud af foretagendet, og det vides ikke, om han, medens han havde med det at gøre, nogen sinde var i forbindelse med Grundtvig, mundtlig eller skriftlig. Arnesen var en højtbegavet sprogmand, men et uroligt gemyt. Han blev senere ordbogsforfatter og især kendt for sin store latinsk-danske ordbog ( $1845^{-}$ 48 ), der stadig bruges.

Selskabet underrettede nu den i 8. maj Grundtvig om det passerede og anmodede ham om at påtage sig hele arbejdet alene. Man bad ham opgive, hvornår han mente, at oversættelsen kunde foreligge fuldført ${ }^{10}$ ).

Grundtvigs svar (det er uheldigvis ikke bevaret i Danmark,
8. Breve I, s. 84 .
9. Fasc. $247,1,7$.
10. Fasc. $247,1,9$. 
men findes muligvis i selskabets arkiv i Oslo; dets hovedindhold kendes dog af selskabets følgende brev) var bejaende, i samme brev foreslog han også selskabet at skrive en fortale til oversættelsen. Herpå kunde ledelsen i Kbh. ikke give noget bestemt svar, da dette var noget nyt, hvortil forinden krævedes sanktion fra Norge. I sit brev angav Gr. også tidspunktet for arbejdets afslutning. (Da brevet mangler, kendes dette tidspunkt ikke). Endvidere oplyste han, at han allerede for nogen tid siden havde lagt hånd på værket.

Et par andre skrivelser mellem Københavnsafdelingen og hovedafdelingen i Norge har mindre interesse her. I Norge sanktionerede man Københavnsafdelingens beslutninger. Gr. fik også, antagelig i I8I3, endnu et brev fra selskabet, hvori man anmodede ham at indsende en prøve på sin oversættelse.

Således gik det altså til med Gr.s engagement som oversætter af Heimskringla. Det var en langstrakt affære: fra Arnesens forslag i november I810 til Gr.s endelige overtagelse af hele arbejdet i sommeren I813. Ejendommeligt nok kender vi ikke noget til Gr.s tanker om oversættelsen ved overtagelsestidspunktet, bortset fra hvad ovenfor er refereret eller citeret. M. h. t. honoraret har det vel i begyndelsen sikkert været en stiltiende forudsætning, at han skulde have det samme som var lovet Arnesen, nemlig ro rdl. for hvert trykt ark, hvad altså betød, at der kunde gå lang tid, før Gr. overhovedet fik nogle penge. Det må dog anses for sandsynligt, at Gr. allerede i 1813 og vel også et stykke ind i 18 I4, har fået nogen pekuniær støtte fra selskabet til oversættelsesarbejdet. Men de økonomisk dårlige tider (statsbankerotten 1813) ramte også selskabets økonomi føleligt, hvad der videre gik ud over Gr. Han opfattede det i 1814, som om selskabet havde »glemt« ham. Dog fortsatte han ufortrødent oversættelsen, som han havde fattet en inderlig kærlighed til, jf. hans ord i fortalen til Snorre I, s. LII.

Som før nævnt havde selskabet mindet Gr. om, at det ved lejlighed ønskede at se en prøve på hans arbejde. Om han virkelig fik indsendt et håndskrevet prøveafsnit vides ikke, men af et bevaret manuskript ses, at han har overvejet at udgive en sådan prøve. Titlen lyder nemlig: »Et Ord til Danske om Snorros Norske Krønike med Prøve af en ny Fordanskning ved Nik. Fred. Sev. Grundtvig Præst «. Disse 14 små sider tekst, som må være skrevet ikke længe efter Norges adskillelse fra Danmark i januar I 8 I 4, udgør en højstemt lovtale over »Saga«, dvs. historiens og fædrenes ånd, som vi ikke må 
glemme, - over Snorres kongesagaer og om de åndelige følger af rigernes adskillelse osv. osv. Gr.s stærke bibeltro ligger overalt tæt under overfladen og viser sig f. eks. i den udtalelse, at adskillelsen ifølge ham skyldtes »Herrens Vrede«. Af selve prøven findes intet, og sandsynligvis er det forblevet ved dette forord alene.

I sin fortale (dateret 12. sept. I818) i første bind af Saxo-oversættelsen fortæller Grundtvig (s. XXX f.), at »(jeg) var ... alt kommet over Midten af Hellig-Olavs Saga; men da faldt det mig som en Steen paa Hjertet, at jeg sad der og udtømde mine Kræfter over Norges Krønike, der nu ikke længer kiærlig sammensmeltede med Dannemarks ... Fædrenelands-Kiærligheden vaagnede med en mig hidindtil af Erfaring ubekiendt glødende Ild og seierrig Vælde i mit Bryst ... og jeg kunde nu ei bære det over mit Hjerte, at udgive Snorros Krønike, med mindre Saxo kunde følges med!«

Spørgsmålet er nu: hvornår fandt denne oplevelse sted? Her er vi så heldigt stillet at være temmelig nøje oplyst, thi i sin fortale til bogen »Imod den lille Anklager《 ( I8I5) skriver han s. 4, at »med gamle Snorro er jeg kommen saavidt, at jeg er kommet hardtad midt ind i Hellig Olavs Saga«. (Her følger en nøjere angivelse af stedet). Denne fortale er dateret 5. januar 1815. Uden at fortabe os i detailler kan vi roligt holde os til begyndelsen af januar ${ }_{18}{ }_{15}$ som det tidspunkt, da han oplevede den opblussen af fædrelandskærlighed, som han sammenligner med »glødende Ild « og »seierrig Vælde«, ret stærke ord! (I et brev til Winsnes i nov. I8I5 bruger han ordene: »at jeg just i Aar skulde fatte det Forsæt at udgive Saxo og Snorro samlede«. Oplevelsen fandt således $\mathrm{i}$ alle tilfælde sted $\mathrm{i}$ I8I $\left.5^{11}\right)$ ). - Nogen årsag kender vi ikke. I Gr.s øvrige forfatterskab ved denne tid findes ingen antydninger. Men hændelsen er meget karakteristisk for Grundtvig: hans åndelige liv var jo en sådan kæde af pludselige og voldsomme vendinger, gæringer, besindelser, anfald af lyst til at tage fat på noget helt nyt. I en selvbiografisk oversigt fra 1824 angiver han 1815 som et år, hvormed en ny periode begyndte $\mathrm{i}$ hans liv: den historiske. ( $18 \mathrm{I} \mathrm{I}-\mathrm{I} 5$ var den teologiske periode). Fra og med 1815 var for ham historien det »som ene omfatter

I I. Breve I, s. 385 . 
alt Menneskeligt«, og som »ogsaa kan og skal forbinde og forklare $\left.\operatorname{det} \ll^{12}\right)$. Der kan næppe være tvivl om, at hans nye, historiske afsnit begyndte ved nytår I8I5 med det faste forsæt også at oversætte $\mathrm{Saxo}^{13}$ ).

Hans beslutning fik vidtrækkende følger. I august samme år opløstes den københavnske afdeling af »Selskabet for Norges Vel $\ll$ og afløstes af et dansk »Selskab for Nordens Oldskrifter«, som nu på formandens, Grundtvigs, tilskyndelse agtede at udgive de to krøniker sammen. En måned efter udsendte Gr. den lille bog »Prøver af Snorros og Saxos Krøniker«, der sluttede med en almindelig opfordring til at bidrage med penge til udgivelsen. Den påfølgende pengeindsamling blev i bogstavelig forstand en landsomfattende affære, pengene strømmede ind fra Danmark, Norge og Hertugdømmerne, og Gr.s navn må på denne måde være blevet kendt til rigets yderste grænser. I slutningen af 18 I 8 forelå første bind af begge krøniker på bogmarkedet. -

Vi skal til at slutte denne lille oversigt. Oversættelsen af Snorre skyldtes således en opfordring udefra, medens oversættelsen af Saxo fremgik af en indre tilskyndelse hos Gr. selv. Man kunde spørge: vilde Gr. have fået ideen til at oversætte Saxo, selv om arbejdet på Snorre ikke var gået forud? Ja, sikkert. I virkeligheden var tanken om en Saxo-oversættelse gammel hos ham. Helt tilbage til studenterårene havde Gr. nu og da studeret Saxo. I I 809 havde historikeren G. L. Baden i et lille skrift bragt spørgsmålet frem om nødvendigheden af en ny oversættelse af Saxo, hvad der også fik Gr. til at foretage et lille oversættelsesforsøg. Men dette var dog rent akademisk og havde intet at gøre med den ånd, der senere drev ham til at oversætte.

Denne ånd eller drivkraft bag ved det hele var Gr.s dengang brændende tro på, at man »ved at fordybe sig i Oldtiden, kunde og skulde gienføde dens Glands $\left.\ll^{14}\right)$. Denne opgave formede sig for

12. Udvalgte Skrifter IV, s. 234 .

I 3. Hvis man tør regne med, at Gr. gerne ved sådanne bevægede vendepunkter blev grebet af en lyst til at se tilbage på sit liv, så er det værd at mærke sig, at han netop den I. jan. I8I5 påbegyndte en »dagbog《, som i virkeligheden var et selvbiografisk tilbageblik. Det går dog ikke til I8I5, men kun til hans tidlige ungdom. Er trykt i Værker i Udvalg I (1940), s. 93-102 (et afsnit udeladt).

14. Nordiske Smaadigte (1838), s. 307 . 
ham som en reel kamp, en kamp mod »Uhyret, der stiler paa at isne eller knuse Nordens Hjerte $\left.\ll^{15}\right)$, dvs. nutidens åndløshed og usselhed. Vil man gå endnu dybere, kan man fæste sig ved en udtalelse af Gr. i i 815. Han siger, at når man føler, at hjælpen kommer fra de gamle dage, vil man »føle sig dobbelt vis derpaa, at Sandheds Kraft omfatter alle Tider, og at hvad som, trods alle Tidens og Slægtens Omskiftelser, beholder Kraft til liflig at røre og styrke, det er af Sandhed. See, derfor arbeider jeg med Lyst og Glæde paa en Oversættelse af Saxos og Snorros kostelige Krøniker om Fædrenelandet $\left.\ll^{16}\right)$. Bag disse ord lå den opfattelse hos ham, at troens kraft beviser troens sandhed. Denne tro på »kraftbeviset《 (som vi ellers ikke skal komme nærmere ind på her) var ret en lære for romantiske digtere og idealister. Kraften er til for at virkeliggøre ideen; kan den det, har den bevist sin sandhed eller virkelighed, rigtighed. Få danske digtere har besiddet en »kraft«, dvs. en åndelig energi, som Gr., og få har »bevist《 så meget som han ved i en strøm af skrifter at tale overbevisende om, hvad han følte og tænkte. I føranførte citat var Gr.s formål at »røre og styrke«. Andre steder har han formuleret det lidt anderledes, og Oehlenschläger og Ingemann har hver på deres vis sagt noget lignende. Genoplivelsen af historiens, fædrenes ånd og kraft, det var det, den danske romantik og da især Gr. vilde. Den danske romantik var i virkeligheden en renæssance.

I denne ånd skal Gr.s to krønikeoversættelser forstås: mere som monumenter fra romantikkens tid end fra middelalderen. $\mathrm{Og}$ den sproglige dragt, som Gr. iklædte dem, bar et så stærkt og ejendommeligt præg af oversætterens personlighed, at de i den henseende er uden mage i vor oversættelseslitteratur. Gr.s Saxo var virkelig, som Hersleb skrev, »fast lige saa meget Original som Oversættelse $\ll^{17}$ ). Og som sådan har krønikerne siden været opfattet i vor litteratur: som værker af Grundtvig!

15. Prøver af Saxos og Snorros Krøniker (1815), s. XXII.

I6. Samme bog s. XXIII.

I 7. Breve I, s. 5 I 3 . 
KILDER

Foruden Grundtvigs efterladte papirer i Det kgl. Bibliotek og deres fortegnelse i Grundtvig-registranten er især konsulteret følgende værker:

Gustav Albeck: Omkring Grundtvigs digtsamlinger. 1955.

M. Birkeland: Selskabet for Norges Vel I809-1829. I86 I.

Steen Johansen: Bibliografi over N. F. S. Grundtvigs skrifter. I-IV, 1948-54. Anders Skrondal: Grundtvig og Noreg. Kyrkje og skule. I8 I 2-72. I929.

O. A. Øverland: Det kgl. Selskap for Norges Vel. I, 1909.

Breve fra og til N. F. S. Grundtvig. I-II, 1924-26. 